\title{
Filamentous fungi isolated from the rhizosphere of melon plants (Cucumis melo L. cv. Gold Mine) cultivated in soil with organic amendments
}

\author{
Flavia Paiva Coutinho ${ }^{1,3}$, Maria Auxiliadora de Queiroz Cavalcanti ${ }^{1}$ and Adriana Mayumi Yano-Melo ${ }^{2}$
}

\author{
Recebido em 21/10/2008. Aceito em 4/12/2009
}

\begin{abstract}
RESUMO - (Fungos filamentosos isolados da rizosfera de meloeiros (Cucumis melo L. cv. Gold Mine) cultivados em solo com compostos orgânicos). Foram coletadas amostras de solo rizosférico em uma área semiárida, na região do Vale do São Francisco, Petrolina, Pernambuco, Brasil, com o objetivo de conhecer a diversidade dos fungos filamentosos presentes em solo cultivado com melão (Cucumis melo cv. Gold Mine) e adubado com diferentes compostos orgânicos: Tratamento 1 (controle, sem adição de compostos orgânicos); T2 (77\% de bagaço de côco, 20\% de esterco de caprino e 3\% de $\mathrm{K}_{2} \mathrm{SO}_{4}$ ); T3 (10\% de torta de mamona, $50 \%$ de capim elefante e $40 \%$ de esterco de caprino); T4 (77\% de bagaço de côco, $20 \%$ de esterco de caprino e $3 \%$ de termofosfato); T5 ( $47 \%$ de capim elefante, $50 \%$ de esterco de caprino e $3 \% \mathrm{~K}_{2} \mathrm{SO}_{4}$ ); e T6 (57\% de capim elefante, $40 \%$ de esterco de caprino e $3 \%$ de termofosfato). O isolamento dos fungos foi realizado por meio da técnica de diluição em série até 1:1000. Foi aplicado o índice de similaridade de Sorensen, e avaliadas a freqüência e a distribuição dos fungos no solo. Setenta e oito espécies foram isoladas e identificadas, além de representantes de Basidiomycota (04) e Mycelia sterilia (02). Os gêneros predominantes foram Aspergillus e Penicillium, com 15 e 13 espécies, respectivamente. Maior número de espécies foi constatado no período de fundação (49), e em relação à adubação orgânica, o tratamento 6 apresentou a maior diversidade (43 espécies). A maioria das espécies encontradas é sapróbia e somente algumas são consideradas potenciais patógenos à cultura do meloeiro, como Fusarium oxysporum, F. solani e Myrothecium roridum.

Palavras-chave: microorganismos, semiárido, Vale do São Francisco, adubação orgânica
\end{abstract}

\begin{abstract}
Filamentous fungi isolated from the rhizosphere of melon plants (Cucumis melo L. cv. Gold Mine) cultivated in soil with organic amendments). Rhizosphere soil samples were collected in a semiarid area, in the region of the São Francisco River valley, Petrolina, Pernambuco state, Brazil, to study the diversity of filamentous fungi in a soil cultivated with melon (Cucumis melo L. cv. Gold Mine) and receiving different organic amendments: Treatment 1 (control, without organic compost); T2 (77\% coconut fiber, $20 \%$ goat manure and $\left.3 \% \mathrm{~K}_{2} \mathrm{SO}_{4}\right)$; $\mathrm{T} 3(10 \%$ Ricinus communis leaves and stems, 50\% Pennisetum purpureum leaves and 40\% goat manure); T4 (77\% coconut fiber, $20 \%$ goat manure and 3\% termophosphate); T5 (47\% Pennisetum purpureum leaves, $50 \%$ goat manure and $3 \% \mathrm{~K}_{2} \mathrm{SO}_{4}$ ); and $\mathrm{T} 6$ (57\% Pennisetum purpureum leaves, $40 \%$ goat manure and $3 \%$ termophosphate). Fungal isolation was carried out by the serial dilution technique to 1:1000. The Sorensen index of similarity, frequency and distribution of the fungi were evaluated. Seventy-eight species of filamentous fungi were isolated and identified, plus several Basidiomycota (04) and Mycelia sterilia (02). The predominant genera were Aspergillus and Penicillium, with 15 and 13 species, respectively. A greater number of species was found in the sowing period (49), and in relation to the organic fertilization, treatment 6 provided the greatest species diversity (43 species). Most of the species are saprobes and only a few are considered to be potential pathogens on melon plants, such as Fusarium oxysporum, F. solani and Myrothecium roridum.

Key words: semiarid, São Francisco River valley, soil amendments, microorganism
\end{abstract}

\section{Introduction}

In Brazil, the culture of melon presented great evolution in the period from 1987 to 2006 , with production of fruits going from 37,980 to 500,021 tons. Melon is largely cultivated and one of the most important products of the Brazilian agribusiness that is conquering greater shares in the national and international markets. The Northeast Region is responsible for about $93 \%$ of the national melon fruits production, with 465,623 tons; the States of Rio Grande do Norte, Ceará, Bahia and Pernambuco are the main producers and exporters (Araújo \& Vilela 2003; IBGE 2006).

The melon (Cucumis melo L.) started to be cultivated in the region of the submedium São Francisco in 1965, in the city of Santa Maria da Boa Vista, Pernambuco State. With the implement of several public projects for irrigation, this agriculture cluster became one of the main zones of production and exportation of fruits in the country. The culture of melon has been intensified in the region, mainly in the cities of Petrolina and Juazeiro, which have better infrastructure for commercialization (Oliveira 1991).

The melon culture in the Vale do São Francisco can be carried out throughout the year, due to the favorable soil and climate conditions, with increased solar radiation, high temperatures and low relative humidity. These factors favor the concentration of total soluble solids in the fruits and diminish the incidence of diseases, increasing the quality of the fruits (Dias et al. 1998).

With the advance of organic agriculture for fruit production in the Submedium São Francisco, many types of residues have been applied; however little is known about the effect of these residues in the soil mycobiota. The type of soil amendment can have a significant effect on the soil mycobiota mainly to favor the saprophytic activity in detriment of potential plant pathogens. Thus, organic residues that favor the increase of natural fungal population are important for improving the nutritional condition of

\footnotetext{
Universidade Federal de Pernambuco, Centro de Ciências Biológicas, Departamento de Micologia, Recife, PE, Brazil

2 Universidade Federal do Vale do São Francisco, Colegiado de Zootecnia, Petrolina, PE, Brazil

3 Corresponding Author: Flavia Paiva Coutinho, flaviapaco@hotmail.com
} 
the cultures of interest in the region and to ensure the sustainability of the organic production.

This work aimed to isolate and identify filamentous fungi from the rhizosphere of melon plants fertilized with distinct organic composts, and to evaluate the influence of these composts in three periods (sowing, flowering and post-harvest) of plant development, relating them to the presence of fungi.

\section{Materials and methods}

Soil sampling - Rhizosphere soil samples were collected using an auger, to a depth of $20 \mathrm{~cm}$, in a semiarid area cultivated with melon (C. melo cv. Gold Mine), in the Vale do São Francisco, Petrolina, Pernambuco State, Brazil $\left(09^{\circ} 32^{\prime} 09^{\prime \prime} \mathrm{S}, 40^{\circ} 55^{\prime} 28^{\prime \prime} \mathrm{W}\right)$, during the periods of sowing, flowering (37 days after sowing) and post-harvest (31 days after flowering), in the months of October, November and December/2005, respectively.

The area was fertilized with the following organic composts (O.C.): Treatment 1 (control, without organic composts); T2 19,7 $\mathrm{m}^{3} \mathrm{ha}^{-1}$ O.C. (77\% coconut fiber, $20 \%$ goat manure and $\left.3 \% \mathrm{~K}_{2} \mathrm{SO}_{4}\right)$; T3 $13,75 \mathrm{~m}^{3}$ ha- ${ }^{-1}$ O.C. ( $10 \%$ Ricinus communis leaves and stems, $50 \%$ Pennisetum purpureum leaves and $40 \%$ goat manure); T4 $13,75 \mathrm{~m}^{3}$ ha ${ }^{-1}$ O.C. ( $77 \%$ coconut fiber, $20 \%$ goat manure and 3\% termophosphate); T5 $9,69 \mathrm{~m}^{3} \mathrm{ha}^{-1}$ O.C. (47\% Pennisetum purpureum leaves, $50 \%$ goat manure and $3 \% \mathrm{~K}_{2} \mathrm{SO}_{4}$ ); and $\mathrm{T} 6$ $6,875 \mathrm{~m}^{3}$ ha ${ }^{-1}$ O.C. (57\% Pennisetum purpureum leaves, $40 \%$ goat manure and $3 \%$ termophosphate). Termophosphate $\left(80 \mathrm{~kg} \mathrm{ha}^{-1} \mathrm{P}_{2} \mathrm{O}_{5}\right)$ and potassium sulphate $\left(60 \mathrm{~kg} \mathrm{ha}^{-1} \mathrm{~K}_{2} \mathrm{O}\right)$ were added to treatments 2 to 6 . Organic composts and termophosphate were applied at planting with $50 \%$ potassium sulphate. Potassium sulphate remains were distributed manually with watering cans in 4 applications, at 6, 13,21 and 27 days after transplanting.

For each treatment, three samples were taken, in a total of 18 samples at each sampling period (sowing, flowering and post-harvest). Consi- dering all treatments, a total of 54 soil samples were investigated for the presence of fungi. The soil (Gray Argisol) samples were chemically analyzed at the Soil Laboratory of the Embrapa Semi-Árido (Tab. 1) (Embrapa 1997).

Isolation and identification of the filamentous fungi - The fungi were isolated using the serial dilution technique (Mehan et al. 1991): $25 \mathrm{~g}$ of each soil sample were suspended in $225 \mathrm{ml}$ of sterilized distilled water (SDW) (1:10); $10 \mathrm{ml}$ of this suspension were added to $990 \mathrm{ml}$ of SDW (1:1000). Then, $1 \mathrm{ml}$ of this suspension was cultured, in triplicate, in Petri dishes containing Sabouraud Agar added of chloranphenicol (500 $\left.\mathrm{mg} \mathrm{l}^{-1}\right)$. The plates were kept at room temperature $\left(28^{\circ} \mathrm{C}\right)$ and the development of colonies was observed until $120 \mathrm{~h}$, when the CFU were estimated. After the first $72 \mathrm{~h}$ the colonies were transferred to Petri dishes with agar medium (potato dextrose agar, czapeck agar and/or malt extract agar) and kept for 20 days, allowing the formation of reproductive structures. The identification of the species was carried out through macroscopic and microscopic observation of the isolates, consulting the specialized literature (Raper et al. 1949; Ames 1961; Corlett 1966; Rifai 1969; Booth 1971; Ellis 1971; Nicoli \& Russo 1974; Samson 1974; Arx 1975; Ellis 1976; Sigler \& Carmichael 1976; Carmichael et al. 1980; Domsch et al. 1980; Sutton 1980; Schipper 1984; Arx et al. 1986; Pitt 1988; Udagawa et al. 1989; Klich \& Pitt 1994; Hanlin \& Menezes 1996).

Statistical analyses - The experimental design was of random blocks in a factorial arrangement $3 \times 6$, with three periods of evaluation (sowing, flowering and post-harvest) and six fertilization treatments (T1, T2, T3, T4, T5 and T6), with three replicates. The values of the CFU were square root ( $\mathrm{x}$ +1 ) transformed before the analysis of variance (ANOVA). The averages were compared by the LSD (least square deviation), $5 \%$ of probability, using the program Statistica 5.0 (Statsoft 1997).

The Sorensen index of similarity (Müller-Dombois \& Ellemberg 1974) was applied to verify the similarity between the fungal populations isolated in the different sampling periods. Frequency and distribution of each fungal species were calculated for each sampling period according to Brower et. al (1990) and Schnitter \& Stephenson (2000).

Table 1. Soil chemical characteristics with and without organic composts fertilization in three periods of the melon plants (C. melo cv. Gold Mine) growing season.

\begin{tabular}{|c|c|c|c|c|c|c|c|c|c|c|}
\hline & Treatment & $\begin{array}{c}\mathrm{OS} \\
\mathrm{g} \mathrm{Kg}^{-1}\end{array}$ & $\mathrm{pH}$ & $\begin{array}{c}\mathrm{EC} \\
\mathrm{d} \mathrm{Sm}^{-1}\end{array}$ & $\begin{array}{c}\mathrm{P} \\
\mathrm{mg} / \mathrm{dm}^{3}\end{array}$ & K & $\mathrm{Ca}$ & $\begin{array}{c}\mathrm{Mg} \\
\mathrm{cmolc} / \mathrm{dm}^{3}\end{array}$ & $\mathrm{Na}$ & CEC \\
\hline \multicolumn{11}{|l|}{$\mathrm{T} 1$} \\
\hline Sowing & & 6.72 & 6.00 & 0.21 & 3.00 & 0.10 & 1.10 & 0.50 & 0.02 & 3.04 \\
\hline Flowering & & 5.48 & 6.43 & 0.12 & 5.75 & 0.09 & 1.30 & 0.43 & 0.02 & 3.70 \\
\hline Post-harvest & & 6.16 & 5.73 & 0.11 & 2.50 & 3.33 & 0.95 & 0.45 & 0.03 & 6.75 \\
\hline \multicolumn{11}{|l|}{$\mathrm{T} 2$} \\
\hline Sowing & & 8.58 & 6.20 & 0.53 & 57.0 & 0.39 & 1.70 & 0.60 & 0.03 & 4.20 \\
\hline Flowering & & 6.73 & 6.98 & 0.20 & 120.75 & 0.21 & 1.50 & 0.65 & 0.04 & 3.26 \\
\hline Post-harvest & & 4.72 & 6.55 & 0.18 & 33.75 & 3.64 & 1.00 & 0.65 & 0.03 & 6.55 \\
\hline \multicolumn{11}{|l|}{$\mathrm{T} 3$} \\
\hline Sowing & & 7.86 & 6.50 & 0.32 & 56.00 & 0.18 & 1.60 & 0.80 & 0.02 & 3.59 \\
\hline Flowering & & 7.89 & 7.20 & 0.19 & 50.75 & 0.16 & 1.90 & 0.73 & 0.03 & 2.82 \\
\hline Post-harvest & & 4.10 & 6.13 & 0.18 & 08.75 & 2.95 & 0.85 & 0.58 & 0.03 & 6.18 \\
\hline \multicolumn{11}{|l|}{$\mathrm{T} 4$} \\
\hline Sowing & & 7.55 & 6.30 & 0.27 & 05.00 & 0.21 & 1.10 & 0.60 & 0.01 & 2.91 \\
\hline Flowering & & 7.99 & 6.68 & 0.14 & 17.00 & 0.20 & 1.58 & 0.63 & 0.02 & 3.08 \\
\hline Post-harvest & & 6.88 & 6.70 & 0.17 & 16.50 & 3.61 & 1.23 & 0.63 & 0.04 & 6.85 \\
\hline \multicolumn{11}{|l|}{$\mathrm{T} 5$} \\
\hline Sowing & & 09.31 & 6.80 & 0.39 & 138.00 & 0.13 & 1.90 & 1.00 & 0.03 & 3.88 \\
\hline Flowering & & 14.95 & 6.93 & 0.18 & 47.00 & 0.18 & 2.18 & 0.80 & 0.03 & 3.51 \\
\hline Post-harvest & & 04.11 & 6.73 & 0.14 & 19.75 & 2.84 & 1.10 & 0.73 & 0.03 & 5.69 \\
\hline \multicolumn{11}{|l|}{$\mathrm{T} 6$} \\
\hline Sowing & & 6.52 & 7.20 & 0.66 & 203.00 & 0.25 & 1.90 & 1.2 & 0.04 & 3.39 \\
\hline Flowering & & 8.25 & 7.08 & 0.21 & 104.25 & 0.20 & 2.00 & 0.8 & 0.04 & 3.44 \\
\hline Post-harvest & & 3.96 & 6.55 & 0.20 & 18.00 & 2.32 & 0.98 & 0.6 & 0.03 & 5.69 \\
\hline
\end{tabular}

$\mathrm{pH}$ (water) $(1: 2.5)$; OS = organic substance; $\mathrm{EC}=$ electrical conductivity; $\mathrm{CEC}=$ cation exchange capacity. $\mathrm{T} 1$ = control, without organic composts; $\mathrm{T} 2=77 \%$ coconut fiber, $20 \%$ goat manure and $3 \%$ $\mathrm{K}_{2} \mathrm{SO}_{4} ; \mathrm{T} 3=10 \%$ Ricinus communis leaves and stems, $50 \%$ Pennisetum purpureum leaves and $40 \%$ goat manure; $\mathrm{T} 4=77 \%$ coconut fiber, $20 \%$ goat manure and $3 \%$ termophosphate; $\mathrm{T} 5=47 \%$ Pennisetum purpureum leaves, $50 \%$ goat manure and $3 \% \mathrm{~K}_{2} \mathrm{SO}_{4}$; $\mathrm{T} 6=57 \%$ Pennisetum purpureum leaves, $40 \%$ goat manure and $3 \%$ termophosphate. 


\section{Results}

Twenty-five genera were isolated, including 78 taxa of filamentous fungi, with predominance of Aspergillus (15 species) and Penicillium (13 species), besides some Basidiomycota (04) and Mycelia sterilia (02), totaling $6,641 \times 10^{4} \mathrm{CFU} \mathrm{g^{-1 }}$ (Tab. 2). Most of the species were anamorphic fungi $(68.75 \%)$, and the remaining were Ascomycota (27.5\%), Zygomycota $(2.5 \%)$ and Basidiomycota (1.25\%).

The variance analysis showed differences in the number of CFU between the sampling periods and between the organic fertilization treatments. A greater number of CFU was evidenced in the sowing period $\left(183.5 \times 10^{4} \mathrm{CFU} \mathrm{g}^{-1}\right)$, differing significantly from the other periods: flowering $\left(85.05 \times 10^{4}\right.$ $\left.\mathrm{CFU} \mathrm{g}{ }^{-1}\right)$ and post-harvest $\left(100.38 \times 10^{4} \mathrm{CFU} \mathrm{g}^{-1}\right)$. In relation to the organic fertilization, treatment 5 yielded a greater number of CFU, followed by treatments 3, 4 and 1 which did not differ significantly. Significant differences were registered only between treatments 5, 2 and 6 (Fig. 1).

There was no difference on species diversity between the sampling periods. A greater number of species was found in the sowing period (49), without significant difference in comparison with the other periods: flowering (39 species) and post-harvest (41 species).

The soil from treatment 6 presented the highest species diversity (43), followed by treatments 2 and 5 ( 39 species), 1 (38 species) and 3 (35 species), which did not differ significantly. Significant difference was registered only between treatments 6 and 4 ( 24 species).

The fungal populations were more similar between the sowing and flowering periods (56.8\% of similarity), followed by the flowering and post-harvest periods $(50 \%)$, while the similarity between the sowing and postharvest periods reached $42.2 \%$. In relation to the organic fertilization, treatments 2 and 3 showed higher similarity in all periods: $59.46 \%$ (sowing), $68.96 \%$ (flowering) and $68.96 \%$ (post-harvest). ("Em relação aos tratamentos de adubação organica, maior similaridade foi observada entre os tratamentos 2 e 3, em todos os períodos fenológicos, 59,46 \% (fundação), 68,96 \% (floração) e 68,96 \% (póscolheita)" veja se ficou claro)

Sixteen taxa were found in the three sampling periods (Tab. 2). Most of the taxa identified in the melon rhizosphere are known as saprobes $(96.25 \%)$ and only a few (3.75\%)

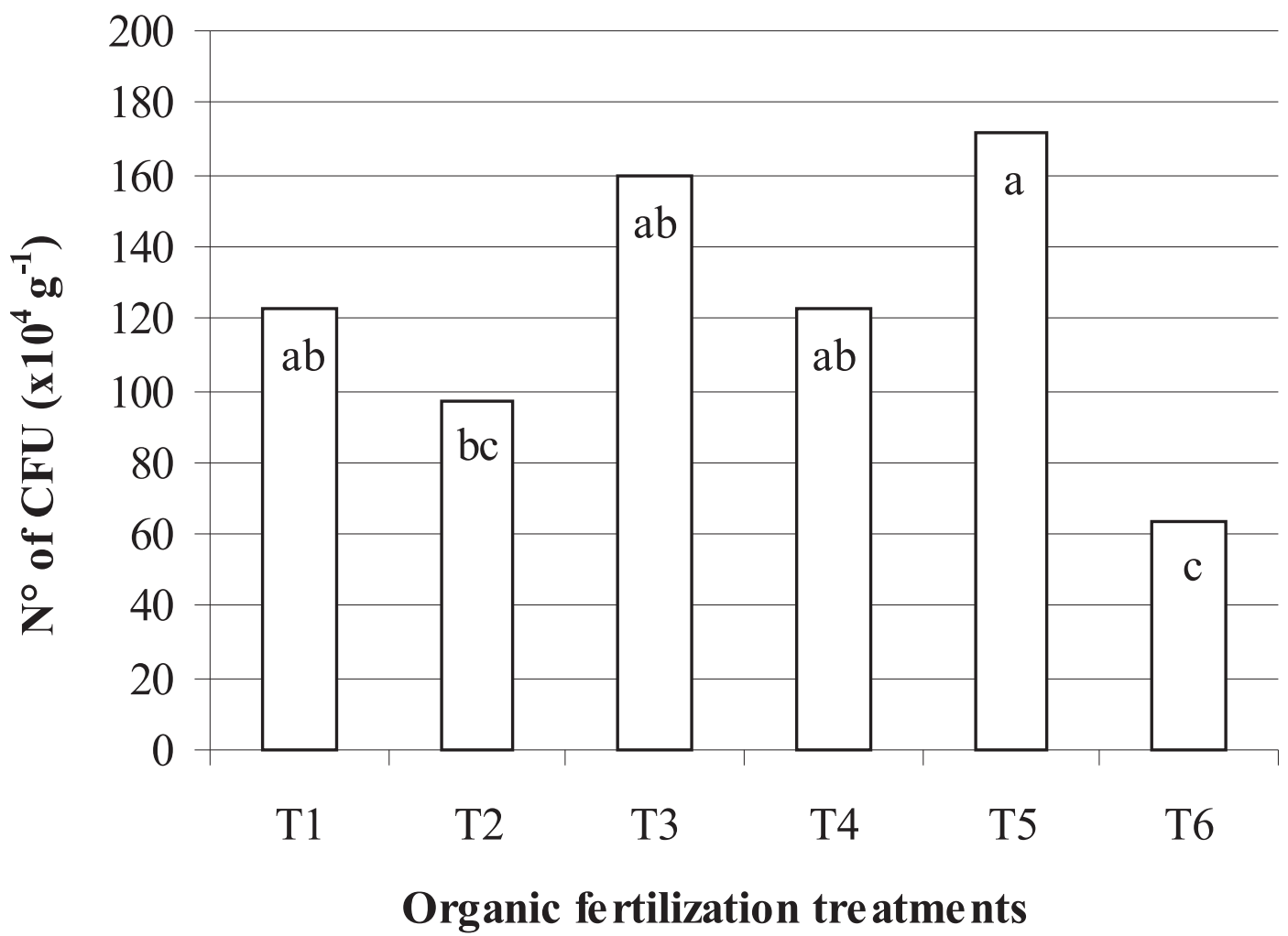

Figure 1. Number of filamentous fungi CFU in the rizhosphere of melon plants fertilized with six types of organic compost: T1 = control, without organic composts; $\mathrm{T} 2=77 \%$ coconut fiber, $20 \%$ goat manure and $3 \% \mathrm{~K}_{2} \mathrm{SO}_{4}$; $\mathrm{T} 3=10 \%$ Ricinus communis leaves and stems, 50\% Pennisetum purpureum leaves and $40 \%$ goat manure; $\mathrm{T} 4=77 \%$ coconut fiber, $20 \%$ goat manure and $3 \%$ termophosphate; $\mathrm{T} 5=47 \%$ Pennisetum purpureum leaves, $50 \%$ goat manure and $3 \% \mathrm{~K}_{2} \mathrm{SO}$; $\mathrm{T} 6=57 \%$ Pennisetum purpureum leaves, $40 \%$ goat manure and 3\% termophosphate. 
Table 2. Filamentous fungi colony forming units (CFU x $10^{4} \mathrm{~g}^{-1}$ ) isolated from the rizhosphere of melon plants (C. melo cv. Gold Mine), fertilized with organic composts, during the sowing, flowering and post-harvest periods.

\begin{tabular}{|c|c|c|c|c|c|c|c|c|c|c|c|c|c|c|c|c|c|c|c|}
\hline \multirow{2}{*}{ Species } & \multicolumn{6}{|c|}{ Sowing } & \multicolumn{6}{|c|}{ Flowering } & \multicolumn{6}{|c|}{ Post-harvest } & \multirow{2}{*}{ Total } \\
\hline & $\mathrm{T} 1$ & $\mathrm{~T} 2$ & $\mathrm{~T} 3$ & $\mathrm{~T} 4$ & T5 & T6 & $\mathrm{T} 1$ & $\mathrm{~T} 2$ & $\mathrm{~T} 3$ & $\mathrm{~T} 4$ & T5 & T6 & $\mathrm{T} 1$ & $\mathrm{~T} 2$ & $\mathrm{~T} 3$ & $\mathrm{~T} 4$ & T5 & T6 & \\
\hline $\begin{array}{l}\text { Alternaria tenuissima (Kunze) } \\
\text { Wiltshire }\end{array}$ & & & & & & 05 & & & & & & & & & & & & & 05 \\
\hline $\begin{array}{l}\text { Aspergillus flavipes (Bainier \& R. } \\
\text { Sartory) Thom \& Church }\end{array}$ & & & & & & & & 03 & & & & & & & & & & 03 & 06 \\
\hline A. flavus Link & 03 & & & & 02 & & & & & & & & & & & & & & 05 \\
\hline A. fumigatus Fresen. & 13 & 66 & 51 & 09 & 13 & 27 & 16 & 21 & 30 & 10 & 13 & 19 & 16 & 28 & 22 & 21 & 10 & 15 & 400 \\
\hline $\begin{array}{l}\text { A. japonicus var. aculeatus (Iizuka) } \\
\text { Al-Musallam }\end{array}$ & & 02 & & & 02 & & & & 10 & & & & & & & & & & 14 \\
\hline A. japonicus var. japonicus Saito & & & 02 & 04 & & & 18 & 03 & 03 & & 45 & & & & 02 & & & 04 & 81 \\
\hline A. nidulans (Eidam) G. Winter & 141 & & & & & 90 & & & & & 07 & & & & & & & & 238 \\
\hline A. niger Tiegh. & 03 & 09 & 61 & 18 & 24 & 02 & 09 & 07 & 01 & 05 & & & 09 & 09 & 05 & 09 & 06 & 02 & 179 \\
\hline A. niger var. niger Tiegh. & 89 & & & & & 03 & & & & & & & & & & & & & 92 \\
\hline $\begin{array}{l}\text { A. sydowii (Bainier \& Sartory) } \\
\text { Thom \& Church }\end{array}$ & & & 02 & & & & & & & & & & & & & & & & 02 \\
\hline A. tamarii Kita & & 02 & & & 02 & & & 02 & & & & & & & & & & & 06 \\
\hline A. terreus Thom & 13 & 175 & 18 & 02 & 22 & 18 & 02 & 02 & 03 & & 19 & 04 & 09 & 22 & 13 & 09 & 03 & 06 & 339 \\
\hline A. terreus var. aureus Thom \& Raper & & & & & & 03 & 05 & 15 & 03 & 02 & & & & 34 & 03 & 97 & & 06 & 168 \\
\hline $\begin{array}{l}\text { A. ungüis (Emile-Weill \& } \\
\text { L. Gaudin) Thom \& Raper }\end{array}$ & 08 & 02 & 03 & & & 07 & & & & & & 02 & & & & & & & 22 \\
\hline A. ustus (Bainier) Thom \& Church & & & & & 02 & 03 & & & & & & & & & & & & & 05 \\
\hline A. viridinutans Ducker \& Thrower & & & & & & & & & & & & & 02 & & 22 & 13 & 10 & 13 & 60 \\
\hline Chaetomium convolutum Chivers & & & & & & & & & & & & & 04 & & & 05 & 03 & & 12 \\
\hline C. cupreum L.M. Ames & & 02 & & & & & & & & & & & & & & & & & 02 \\
\hline C. leucophorum L.M. Ames & 02 & & & & & & & & & & & & & & & & & & 02 \\
\hline C. nigricolor L.M. Ames & & & & & & & & & & & & & & 09 & & 03 & & & 12 \\
\hline C. ochraceum Tschudy & & & & & & 02 & & 10 & & & 10 & & & & & & & & 22 \\
\hline $\begin{array}{l}\text { C. trigonosporum (Marchal \& É.J. } \\
\text { Marchal) Chivers }\end{array}$ & & & & & & & 06 & 02 & & 06 & & 06 & & & & & 03 & & 23 \\
\hline Cladosporium sphaerospermum Penz. & & 03 & & & & & & & & & 02 & & & & & & & & 05 \\
\hline C. tenuissimum Cooke & & 03 & 05 & & & & & & & & & & & & & & & & 08 \\
\hline $\begin{array}{l}\text { Curvularia eragrostidis (Henn.) } \\
\text { J.A. Mey. }\end{array}$ & & & 04 & & & & & & & & & & & & & & & & 04 \\
\hline Emericella nidulans (Eidam) Vuill. & 13 & 37 & 561 & 421 & 404 & 03 & 37 & 02 & 06 & 72 & 286 & & 121 & 13 & 07 & & & 45 & 2028 \\
\hline E. nidulans var. acristata Subram. & 300 & 60 & 157 & & 31 & 09 & 85 & 22 & 105 & 163 & 145 & 37 & 03 & 21 & 169 & 120 & 34 & 66 & 1527 \\
\hline E. nidulans var. echinulata Godeas & 07 & & & & & 21 & 09 & 06 & 04 & 06 & 02 & & 30 & & & & & 06 & 91 \\
\hline E. rugulosa (Thom \& Raper) C.R. Benj. & & & & & & & 02 & & & & & & & & & & & & 02 \\
\hline E. variecolor Berk. \& Broome & & & & & 02 & & & & & & & & & & & & & & 02 \\
\hline $\begin{array}{l}\text { Eupenicillium brefeldianum (B.O. } \\
\text { Dodge) Stolk \& D.B. Scott }\end{array}$ & 06 & & & & & & & & & & & & & & & & & & 06 \\
\hline E. crustaceum F. Ludw. & & & & & & & 02 & & & & & & & & & & & & 02 \\
\hline Eurotium chevalieri L. Mangin & & & & & & & & 03 & 03 & & & 02 & 02 & & & & & & 10 \\
\hline E. rubrum W. Bremer & & & & & & & & 02 & & & & & & & & & & & 02 \\
\hline Fusarium equiseti (Corda) Sacc. & & & & & & & & 02 & & & & & & & & & & & 02 \\
\hline F. merismoides Corda & 18 & & & & 02 & & & & & & & & & & & & & & 20 \\
\hline F. oxysporum Schltdl. & & & & 02 & & & & & & & & & & 02 & 03 & & & & 07 \\
\hline F. redolens Wollenw. & 02 & & & & & & & & & & & & & & & & & & 02 \\
\hline F. solani (Mart.) Sacc. & 04 & & & & & 02 & & 04 & 07 & 02 & & & 02 & & 04 & & 02 & 02 & 29 \\
\hline F. stilboides Wollenw. & & & & & & & & & & & & & & & 02 & & & 02 & 04 \\
\hline $\begin{array}{l}\text { Gliocladium virens J.H. Mill., } \\
\text { Giddens \& A.A. Foster }\end{array}$ & & 03 & & & & & & & & & & & & & & & & & 03 \\
\hline Humicola fuscoatra Traaen & 02 & 04 & 03 & & & 02 & & & & & & & 02 & 02 & & & 02 & & 17 \\
\hline Monodictys castaneae (Wallr.) S. Hughes & & & 02 & & & 02 & & & & & & & & & & & & & 04 \\
\hline Myrothecium. roridum Tode & & & & & & & & 07 & & & 03 & 03 & & & & & & & 13 \\
\hline M. verrucaria (Alb. \& Schwein.) Ditmar & & & & & 02 & 02 & & & 02 & & & & & & & & & & 06 \\
\hline $\begin{array}{l}\text { Neocosmospora vasinfecta var. } \\
\text { africana (Arx) P.F. Cannon \& D. } \\
\text { Hawksw. }\end{array}$ & 05 & 03 & 02 & 27 & 43 & 03 & 06 & 02 & 03 & 02 & & & & 02 & & & & & 98 \\
\hline $\begin{array}{l}\text { Neoscytalidium dimidiatum (Penz.) } \\
\text { Crous \& Slippers }\end{array}$ & & & & & & 02 & & & & & & & & & & & & & 02 \\
\hline $\begin{array}{l}\text { Paecilomyces carneus (Duché \& R. } \\
\text { Heim) A.H.S. Br. \& G. Sm. }\end{array}$ & & & & 07 & & & & & & & & & & & & & & & 07 \\
\hline P. lilacinus (Thom) Samson & 07 & & & & & & & & & & & & & & & & 21 & & 28 \\
\hline P. variotii Bainier & & & & & & & & & & 03 & & & & & & & & & 03 \\
\hline
\end{tabular}




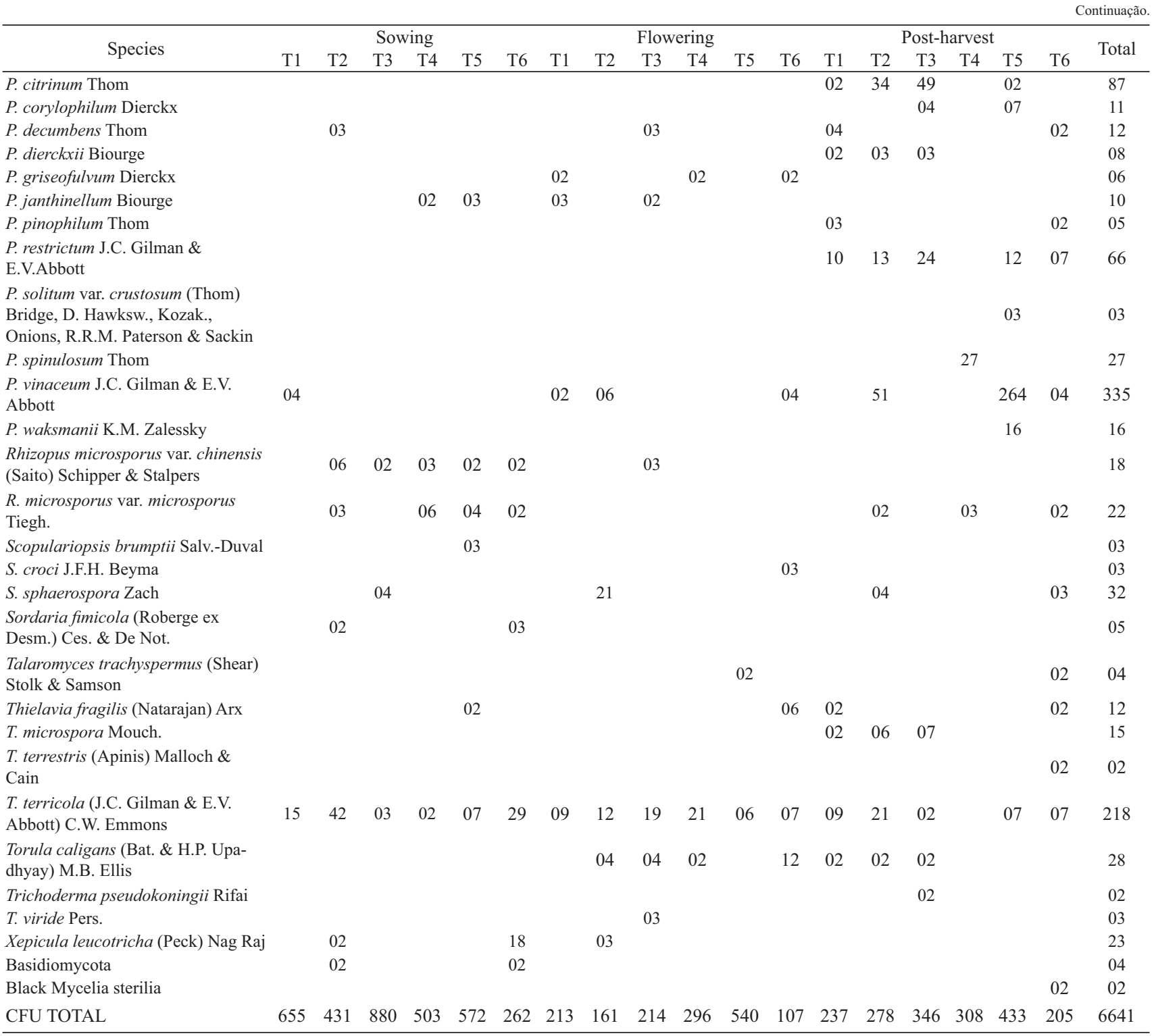

$\mathrm{T} 1=$ control, without organic composts; $\mathrm{T} 2=77 \%$ coconut fiber, $20 \%$ goat manure and $3 \% \mathrm{~K}_{2} \mathrm{SO}_{4} ; \mathrm{T} 3=10 \%$ Ricinus communis leaves and stems, $50 \%$ Pennisetum purpureum leaves and $40 \%$ goat manure; $\mathrm{T} 4=77 \%$ coconut fiber, $20 \%$ goat manure and $3 \%$ termophosphate; T5 $=47 \%$ Pennisetum purpureum leaves, $50 \%$ goat manure and $3 \% \mathrm{~K}_{2} \mathrm{SO}_{4} ; \mathrm{T}_{6}=57 \%$ Pennisetum purpureum leaves, $40 \%$ goat manure and $3 \%$ termophosphate.

are referred to as potential plant pathogens: Fusarium oxysporum, F. solani and Myrothecium roridum.

Most of the fungi was classified as rare; however Emericella nidulans and E. nidulans var. acristata were abundant. All the species presented low frequencies of occurrence.

\section{Discussion}

Most of the fungi found in the melon rhizosphere was registered in rhizosphere and non-rhizosphere soils in Brazil and other countries (Silva \& Cavalcanti 1990, 1991; Cavalcanti \& Maia 1994; Maia \& Gibertoni 2002; Mandeel 2002; Souza-Motta et al. 2003; Ananda \& Sridhar 2004; Cavalcanti et al. 2006; Costa et al. 2006; Grishkan et al. 2006).
Studying the microfungi of the rhizosphere of Zygophyllum qatarense Hadidi, in a semiarid environment of Bahrain, Mandeel (2002) reported the predominance of species of Aspergillus and Penicillium. Similarly, Grishkan et al. (2006) found species of Penicillium and Aspergillus to be the most abundant in the rhizosphere of native plants of Negev, Israel. These results are similar to the findings of this work, considering that Aspergillus and Penicillium are well represented in the studied area, with 15 (18.75\%) and $13(16.25 \%)$ species, respectively.

In the Brazilian semiarid region, Silva \& Cavalcanti (1990; 1991) registered Fusarium and Penicillium as predominant in the rhizosphere of tomato (Lycopersicon esculentum Mill). Maia \& Gibertoni (2002) reported a 
great diversity of soil fungi in the Brazilian semiarid, with predominance of: Aspergillus, Cladosporium, Fusarium, Humicola, Myrothecium, Paecilomyces, Penicillium, Rhizopus and Trichoderma. Species of Aspergillus and Penicillium predominated in soil from a copper mining impacted area (Costa et al. 2006) in Bahia State. Likewise, Cavalcanti et al. (2006) registered several filamentous fungi in soils from the Xingó region (Sergipe and Alagoas States), with predominance of Penicillium and Aspergillus species. Several of the fungal species found here were reported in areas of the Brazilian semiarid region (Maia \& Gibertoni 2002; Cavalcanti et al, 2006; Costa et al. 2006).

The prevalence of Aspergillus and Penicillium occurs probably because these genera have a high number of species and are capable of surviving in dry environments (Dix \& Webster 1995).

Three of the species found in this study were previously regarded as pathogen to melon plants: Fusarium oxysporum, F. solani and Myrothecium roridum (Marinho et al. 2002; Muniz et al. 2004; Viana et al. 2001). However, it is not possible to say if they were in the rhizosphere as saprobe or pathogen. These species were also registered, respectively, in the rhizosphere of sugar-cane, tomato and sunflower (Santos \& Cavalcanti 1989; Silva \& Cavalcanti 1990, 1991; Souza-Motta et al. 2003). In the present work these species showed an occasional distribution.

The organic fertilization in the melon plants favored the presence of filamentous fungi and increased the number of CFU. It also allowed a wide distribution of saprophytic fungi, considering that $96.25 \%$ of the species isolated in this study have been described as organic matter decomposers. Therefore, the introduction of organic composts can improve the soil quality in the culture of melon by increasing the diversity and number of fungi.

The phenology of the melon plants did not affect the diversity of filamentous fungi; however, it significantly decreased the amount of CFU. The highest number of CFU was observed in the sowing period, probably due to the processes of incorporation and mineralization of the organic residues in the soil, resulting in an increase of the cation exchange capacity (CEC) in the subsequent periods (Tab. 1). Except for treatments 5 and 6, the quantity of organic matter in the soil was higher in the sowing period, increasing the offer of substrate for decomposition that was reflected in the highest number of CFU in this period.

The analysis of similarity showed a lower index between the fungi in the sowing and the post-harvest periods. According to Melnitchouk et al. (2005) and Wellbaum et al. (1999), this may be associated with the changes in the composition of root exudates over the phenological cycle of the plant, causing variation in the rhizodeposition, and with the hydrosoluble substances released by decomposition of organic matter, which represent an energy source promptly available for the microorganisms. In addition, Parkinson et al. (1963) apud Souza-Motta et al. (2003) mentioned that the young roots are initially colonized by a diversity of soil fungi which after some days are substituted by a more restricted mycobiota that remains until the senescence of the roots.

The results attained in this study suggest that anamorphic fungi dominate the soil mycobiota of cultivated melon fields in the Brazilian semiarid, and that species of Aspergillus and Penicillum are the most commonly found. Furthermore, the data indicate that the composition of the rhizosphere interfere in the fungal succession.

\section{Acknowledgements}

The authors would like to acknowledge: Coordenação de Aperfeiçoamento de Pessoal de Nível Superior (CAPES), Conselho Nacional de Desenvolvimento Científico e Tecnológico (CNPq), Empresa Brasileira de Pesquisa Agropecuária (Embrapa Semi-Árido), Programa de Pós-Graduação em Biologia de Fungos/Universidade Federal de Pernambuco (UFPE) for the support to the project, and Dra. Elaine Malosso and Leonardo Costa for the English review.

\section{References}

Ananda, K. \& Sridhar, K.R. 2004. Diversity of filamentous fungi on decomposing leaf and woody litter of mangrove forests in the southwest coast of India. Current Science of India 87(10): 1431-1437.

Ames, L.M. 1961. A monograph of the Chaetomiaceae. Washington, U.S. Army Research and Development.

Araújo, J.L.P. \& Vilela, N.J. 2003. Aspectos Socioeconômicos. Pp. 1518. In: H.R. Silva \& N.D. Costa (eds.). Frutas do Brasil 33: melão, produção e aspectos técnicos. Brasília, Embrapa.

Arx, J.A. von. 1975. On Thielavia and some similar genera of Ascomycetes. Studies in Mycology 8: 1-31.

Arx, J.A. von; Guarro, J. \& Figueras, M.J. 1986. The ascomycete genus Chaetomium. Nova Hedwigia 84: 1-162.

Booth, C. 1971. The genus Fusarium. Kew, Commonwealth Mycological Institute.

Brower, J.E.; Zar, J.H. \& Von Ende, C.N. 1990. Field and laboratory methods for general ecology. Dubuque, McGraw-Hill.

Carmichael, J.W.; Kendrick, B.; Conners, I.L. \& Sigler, L. 1980. Genera of Hyphomycetes. Edmonton, University of Alberta Press.

Cavalcanti, M.A.Q. \& Maia, L.C. 1994. Cellulolytic fungi isolated from an alluvial soil in a semi-arid area of the northeast of Brazil. Revista de Microbiologia 25: 251-254.

Cavalcanti, M.A.Q.; Oliveira, L.G.; Fernandes, M.J. \& Lima, D.M. 2006. Fungos filamentosos isolados do solo em municípios na região Xingó, Brasil. Acta Botanica Brasilica 20(4): 831-837.

Corlett, M. 1966. Perithecium devolopment in Chaetomium trigonosporum. Canadian Journal of Botany 44: 155-162.

Costa, I.P.M.W.; Cavalcanti, M.A.Q.; Fernandes, M.J.S. \& Lima, D.M.M. 2006. Hyphomycetes from soil of an area affected by copper mining activities in the state of Bahia, Brazil. Brazilian Journal of Microbiology 37: 267-275.

Dias, R.C.S.; Costa, N.D.; Silva, P.C.G.; Queiroz, M.A.; Zuza, F.; Leite, L.A.S.; Pessoa, P.F.A.P. \& Terão, D. 1998. A cadeia produtiva do melão no Nordeste. Pp. 441-494. In: A.M.G. Castro; S.M.V. Lima; W.J. Goedart; A. Freitas Filho \& J.R.P. Vasconcelos (eds.). Cadeias produtivas e sistemas naturais: prospecção tecnológica. Brasília, Embrapa.

Dix, N.J. \& Webster, J. 1995. Fungal ecology. London, Chapman \& Hall.

Domsch, K.H.; Gams, W. \& Anderson, T.H. 1980. Compendium of Soil Fungi. London, Academic Press.

Ellis, M.B. 1971. Dematiaceous Hyphomycetes. Kew, Commonwealth Mycological Institute

Ellis, M.B. 1976. More Dematiaceous Hyphomycetes. Kew, Commonwealth Mycological Institute.

Embrapa. 1997. Manual de Métodos de Análise de Solo. Rio de Janeiro, Centro Nacional de Pesquisa de Solos.

Grishkan, I.; Zaady, E. \& Nevo, E. 2006. Soil crust microfungi along a 
southward rainfall gradient in desert ecosystems. Journal of Arid Environments 53(3): 409-417.

Hanlin, R.T. \& Menezes, M. 1996. Gêneros ilustrados de Ascomicetos. Recife, Imprensa da Universidade Federal Rural de Pernambuco.

IBGE. 2006. Produção agrícola. http://www.sidra.ibge.gov.br/bda/tabela/ listabl.asp? $\mathrm{c}=1612 \& \mathrm{z}=\mathrm{p} \& \mathrm{o}=20$ (accessed 20/02/2008).

Klich, M.A. \& Pitt, J.I. 1994. A laboratory guide to common Aspergillus species and their teleomorphs. North Ryde, CSIRO Division of Food Processing.

Maia, L.C. \& Gibertoni, T.B. 2002. Fungos registrados no semi-árido nordestino. Pp. 163-176. In: E.V.S.B. Sampaio; A.M. Giulietti; J. Virginio \& C.F.L. Guamarra-Rojas (eds.). Vegetação \& Flora da Caatinga. Recife, Centro Nordestino de Informações sobre Plantas.

Mandeel, Q.A. 2002. Microfungal community associated with rhizosphere soil of Zygophyllum qatarense in arid habitats of Bahrain. Journal of Arid Environments 50(4): 665-681.

Marinho, R.E.M.; Sales Jr, R.; Maracajá, P.B.; Silva, G.F.; Costa, F.M. \& Silva, E.C. 2002. Identificação da micoflora associada a raízes de meloeiro nos estados do Rio Grande do Norte e Ceará. Caatinga 15(1/2): 25-28

Mehan, V.K.; Mayee, C.D.; Jayanthi, S. \& McDonald, M. 1991. Preharvest seed infection by Aspergillus flavus group fungi and subsequent aflatoxin contamination in groundnuts in relation to soil types. Plant and Soil 136(2): 239-248.

Melnitchouk, A.; Leinweber, P.; Eckhardt, K.U. \& Beese, R. 2005. Qualitative differences between day-and night-time rhizodeposition in maize (Zea mays L.) as investigated by pyrolysis-field ionization mass spectrometry. Soil Biology \& Biochemistry 37: 155-162.

Müller-Dombois, D. \& Ellemberg, H. 1974. Aims and methods of vegetation ecology. New York, John Wiley \& Sons.

Muniz, M.F.B.; Gonçalvez, N. \& Garcia, D.C. 2004. Qualidade fisiológica e sanitária de sementes de melão (Cucumis melo). Ciência Rural 34(3): 951-953.

Nicoli, R.M. \& Russo, A. 1974. Le genre Humicola Traaen et les genres voisins (Hyphomycetes). Nova Hedwigia 25: 737-781.

Oliveira, A.C. 1991. Impactos econômicos da irrigação sobre o pólo Petrolina-Juazeiro. Recife, UFPE/PIMES.

Pitt, J.I. 1988. A laboratory guide to common Penicillium species. North Ryde, CSIRO Division of Food Processing.
Raper, K.B.; Thom, C. \& Fennel, D.I. 1949. A manual of the Penicillia. Baltimore, Williams \& Wilkins Company.

Rifai, M.A. 1969. A revision of the genus Trichoderma. Mycological Papers 116: 1-56.

Samson, R.A. 1974. Paecilomyces and some allied Hyphomycetes. Studies in Mycology 6: 1-68.

Santos, A.C. \& Cavalcanti, M.A.Q. 1989. Fungos isolados da rizosfera da cana-de-açúcar da zona da mata de Pernambuco. Revista Brasileira de Botânica 12(1): 23-29.

Schipper, M.A.A. 1984. A revision of the genus Rhizopus: I. The Rhizopus stolonifer-group and Rhizopus oryzae. Studies in Mycology 25: 1-34.

Schnittler, M. \& Stephenson, S.L. 2000. Myxomycete biodiversity in four different forest types in Costa Rica. Mycologia 92: 626-637.

Sigler, L. \& Carmichael, J.W. 1976. Taxonomy of Malbranchea and some other hyphomycetes with arthroconidia. Mycotaxon 4: 349-488.

Silva, M.I.L. \& Cavalcanti, M.A.Q. 1990. Fungos na rizosfera de sementes de tomate. Fitopatologia Brasileira 15(4): 323-326.

Silva, M.I.L. \& Cavalcanti, M.A.Q. 1991. Hongos associados a semillas de tomate (Lycopersicon esculentum). Boletín Micologico 06(1/2): 59-62.

Souza-Motta, C.M.; Cavalcanti, M.A.Q.; Fernandes, M.J.S.; Lima, D.M.M.; Nascimento, J.P. \& Laranjeira, D. 2003. Identification and characterization of filamentous fungi isolated from the sunflower (Helianthus annus L.) rhizosphere according to their capacity to hydrolyse inulin. Brazilian Journal of Microbiology 34(3): 273-280.

Statsoft Inc. 1997. Statistica for Windows (Computer Program Manual). Tulsa, Statsoft Inc.

Sutton, B.C. 1980. The Coelomycetes: Fungi imperfecti with pycnidia, acervuli and stromata. Kew, Commonwealth Mycological Institute.

Udagawa, S.I.; Horie, Y. \& Cannon, P.F. 1989. Two new species of Neocosmospora from Japan, with a key to the currently accepted species. Sydowia 41: 349-359.

Viana, F.M.P.; Santos, A.A.; Freire, F.C.O.; Cardoso, J.E. \& Vidal, J.C. 2001. Recomendações para o controle das principais doenças que afetam a cultura do melão na Região Nordeste. http://www.cnpat.embrapa. br/home/down/index.php?pub/ct_12.pdf (accessed 02/07/2007).

Wellbaum, C.; Schoenlein-Crusius, I.H. \& Santos, V.B. 1999. Fungos filamentosos em folhas do ambiente terrestre e aquático da Ilha dos Eucaliptos, Represa do Guarapiranga, São Paulo, SP. Revista Brasileira de Botânica 22(01): 69-74. 